\title{
Herbage Standing Crop around Eastern Redcedar Trees
}

\author{
D.M. ENGLE, J.F. STRITZKE, AND P.L. CLAYPOOL
}

\section{Abstract}

The effect of eastern redcedar (Juniperus virginiana) on understory herbage standing crop was investigated in northcentral Oklahoma tallgrass prairies. Herbage standing crop was measured under and at distances radiating away from individual trees of 2 height classes ( $2 \mathrm{~m}$ and $6 \mathrm{~m}$ ) in 1984 and 1985. Soil water content at 2 distances from eastern redcedar trees and tree leaf water content were examined from 1982 to 1984 . There was marked reduction in herbage production beneath the tree canopy, only slight reduction at the dripline, and little herbage reduction beyond the dripline. Tree height did not significantly influence herbage standing crop. Thus, herbage reduction is directly related to tree canopy area. Therefore, herbage reduction would be minimal in the early stages of tree encroachment when canopy is small. Soil water content at the tree dripline was sometimes lower than that $3 \mathrm{~m}$ outside the dripline, but the differences were small. Leaf water content generally followed the seasonal trend of soil water content. Burning in late spring is an appropriate prescription for eastern redcedar control since leaf water content is relatively low in late spring.

Key words: Juniperus, brush control, tallgrass prairie, interference, competition

Eastern redcedar (Juniperus virginiana) is the eastern-most juniper species in North America and is indigenous to every state east of the 100th meridian (Van Haverbeke and Read 1976). Historically, fire prevented eastern redcedar encroachment into tallgrass prairies and forest meadows of the central United States (Arend 1950). With the reduced incidence of fire in the last 100 years, eastern redcedar has become a prominent component of rangelands in Oklahoma. In 1950 there were 600,000 ha of Oklahoma's rangeland infested with eastern redcedar and by 1985, the infestation had increased to over 1,400,000 ha (Snook 1985).

Springfield (1976) concluded that individual juniper (Juniperus spp.) trees have the ability to compete for scarce resources, and as a result, influence species composition and growth of understory plants far beyond their canopy. Arnold (1964) described a zonal pattern of species composition and yield differences encircling one-seed juniper ( $J$. monosperma) in Arizona. Numerous studies in the western United States have reported increases in forage production following control of junipers (Arnold et al. 1964, Aro 1971, Clary 1971, Clary 1974, Steuter and Wright 1983, Everett and Sharrow 1985). Some of these forage production increases may have been confounded with site disturbance, since site disturbance was a part of the control treatments. However, zonation patterns are often visible around juniper trees in the western United States, but are not readily visible around eastern redcedar trees.

Because earlier burning reduces forage production, late spring burning (April 15-May 1) is the recommended burning season for eastern redcedar control (Launchbaugh and Owensby 1978). Leaf water content, which is highly correlated to ignition time of redberry juniper ( $J$. pinchotii) (Bunting et al. 1983), might be a key element in timing of fires for eastern redcedar control. Perhaps in combination with soil water content, leaf water content may be a useful indicator of leaf flammability and provide a more appropriate season prescription for eastern redcedar control by burning

Currently, there are no data on the effect of eastern redcedar on herbage production in tallgrass prairie or on seasonal changes in leaf water content of trees. Hence, the objectives of these studies

\footnotetext{
Authors are associate professor and professor, Agronomy Department, and professor, Statistics Department, Oklahoma State University, Stillwater 74078.

Oklahoma Agricultural Experiment Station Journal Contribution No. 5050.

Manuscript accepted 8 December 1986.
}

were to determine the effect of eastern redcedar on herbage standing crop at various distances from the tree, to compare the effect of 2 tree sizes on herbage standing crop, and to examine annual cycles of leaf water content and soil water content at 2 distances from individual trees.

\section{Methods and Materials}

Three separate experiments were conducted on tallgrass prairies located in Payne County, Oklahoma, about $18 \mathrm{~km}$ southwest of Stillwater. Study areas for all 3 experiments were estimated to be in good to excellent range condition with no grazing in the year of sampling. Major herbaceous species in the study areas included little bluestem (Schizachyrium scoparium), indiangrass (Sorghastrum nutans), switchgrass (Panicum virgatum), big bluestem (Andropogon gerardii), and sedges (Carex spp.).

Experiment I was located on an eroded prairie range site. A two-way classification with trees as main units (8 trees) and distance from the tree (beneath the canopy, at dripline, and 1 and $3 \mathrm{~m}$ beyond dripline) as subunit treatments nested within trees was used to assess the effects of trees on herbage standing crop in 1984. The standing crop of current year's herbage growth at each sample location was clipped at ground level from four $0.25 \mathrm{~m}^{2}$ quadrats in early August. Clipped samples were dried at $65^{\circ} \mathrm{C}$ to a constant moisture content.

The soil and leaf water content were monitored at this site in 1982,1983 , and 1984 . Soil water content was determined monthly (see Fig. 2 for months). The neutron scatter method was used to

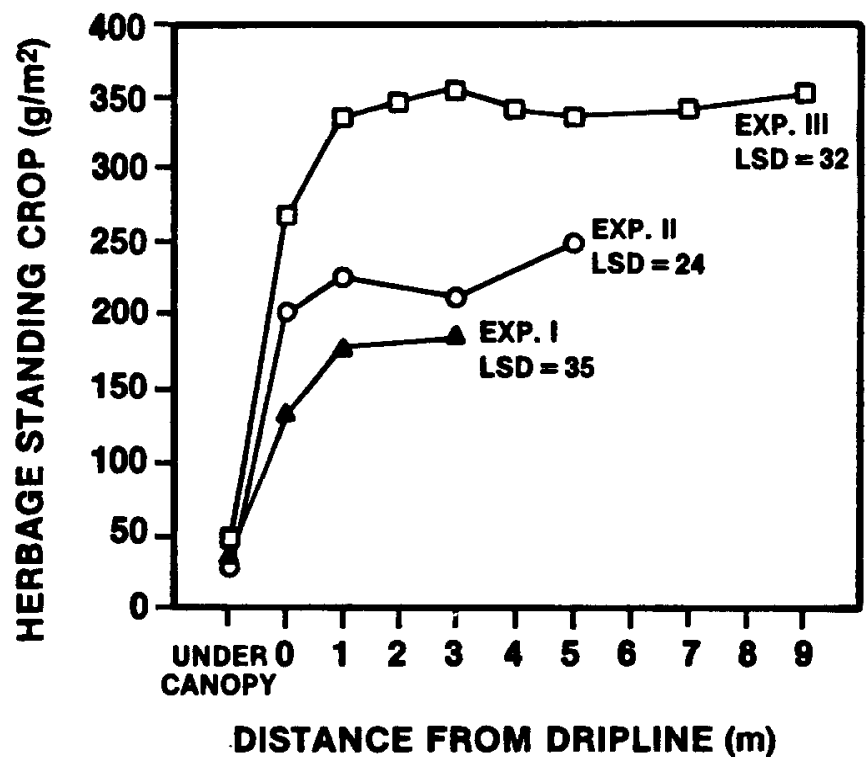

Fig. 1. Herbage standing crop as influenced by indidvidual eastern redcedar trees in tallgrass prairie in 1984 and $1985(n=8,96$, and 64 for Experiments I, II, and III, respectively).

measure soil water to a depth of $120 \mathrm{~cm}$ at the dripline and $3 \mathrm{~m}$ beyond dripline at each of 6 randomly located trees $(2$ to $3 \mathrm{~m}$ height). Soil water data were analyzed as a paired experiment at each date. Leaf water content was gravimetrically determined on the same dates by clipping leaves at mid-day from 8 randomly located trees and drying at $65^{\circ} \mathrm{C}$. Leaf water data were analyzed as 
repeated measures over time with each tree as a block.

Herbage measurements were also taken in 1984 at a second study area (Experiment II) located on previously cultivated eroded prairie, eroded sandy savannah, and shallow savannah range sites that had naturally revegetated to tallgrass prairie. In 1985 (Experiment III) the study areas included previously cultivated and virgin tallgrass prairie.

A split-plot in a randomized complete block was used with 3 pastures as blocks in Experiment II and 3 range sites (eroded prairie, loamy prairie, and shallow prairie) as blocks in Experiment III. Two tree heights $(2 \mathrm{~m}$ and $6 \mathrm{~m}$ ) were main unit treatments in Experiments II and III. In Experiment II there were 5 distances as subunit treatments (beneath the canopy, at dripline and 1, 3 and 5 $m$ beyond the dripline). In Experiment III there were 9 distances as subunit treatments (beneath the canopy, at dripline, and $1,2,3,4$, 5,7 and $9 \mathrm{~m}$ behond the dripline). The standing crop of current year's herbage growth was clipped in late July in Experiments II and III from each of 4 subsamples in a concentric pattern around each tree.

From the analysis of variance procedure, $F$ tests were performed to test for differences in herbage standing crop associated with tree height and distance from tree. In the presence of a significant $F$ value, treatment means were separated by LSD at the $95 \%$ significance level.

\section{Results and Discussion}

Herbage standing crop was definitely reduced around eastern redcedar trees (Fig. 1). Tree height had no effect $(P>0.10)$ on herbage standing crop in either Experiment II or III. Therefore, data from these 2 experiments were averaged over tree height. There was very little herbage beneath the tree canopy in all 3 experiments. Herbage standing crop was generally less at the dripline than beyond the dripline, especially in 1985 ( $P<0.0001)$; but, at $1 \mathrm{~m}$ from the dripline, standing crop was not significantly different from the maximum standing crop in all 3 experiments. In Experiment $I$, the herbage standing crop was the same at 1 and $3 \mathrm{~m}$ from the dripline; but, in Experiment II, there was significantly less herbage at $3 \mathrm{~m}$ than at $5 \mathrm{~m}$ from the dripline. A similar influence on herbage growth beyond the canopy has been reported for one-seed juniper and was attributed to more competition for soil water by juniper root hairs in this zone (Arnold 1964, Jameson 1970). Precipitation in 1985 for Experiment III was $152 \%$ of long-term average for November to July, and there was no herbage standing crop reduction at any distance beyond the canopy. The less overall herbage standing crop in 1984 (Experiments I and II), and the reduction in herbage standing crop at $3 \mathrm{~m}$ in Experiment II might be associated with precipitation in 1984 , which was $89 \%$ of longterm average. Since most of the herbage reduction was beneath the tree canopy, shading and allelopathy from the tree could be major factors associated with herbage reduction.

Reduction of forage production by junipers on western rangelands is proportional to tree canopy size and tree density (Arnold et al. 1964, Jameson 1967). This relationship also applies to tallgrass prairie invaded by eastern redcedar since our data indicate that the primary effect of eastern redcedar on herbage production is beneath the canopy. However, in contrast to the junipers on the more arid western rangelands, which may severely depress forage production with fairly sparse stands and open canopies, there would be a negligible overlapping of the zones of influence of individual eastern redcedar trees, except perhaps in dry years or in drier climates, until canopy closure resulted.

Soil water content reflected precipitation and plant growing season demand for water (Fig. 2). Thus, soil water content reached a low point in late summer and early fall of all 3 years. Leaf water content generally followed the same trend as soil water content. Leaf water content was not at a marked low point in any single season. However, there were noticeable increases in leaf water content in early summer, which corresponds to the period of optimum growing conditions and leaf water status of herbaceous plants in central Oklahoma tallgrass prairies (Hake et al. 1984). Soil water content at the dripline was significantly $(P<0.002)$ lower than that $3 \mathrm{~m}$ outside the dripline of eastern redcedar trees on several dates from 1982 to 1984 . It appears that competition for water by eastern redcedar would not be a major factor in herbage production at $3 \mathrm{~m}$ from the tree canopy in tallgrass prairie.

\section{Conclusions}

The influence of eastern redcedar on herbage production surrounding individual trees appears to be primarily restricted to beneath the tree canopy. The slight reduction in herbage standing crop at the dripline sampling location is possibly a result of including a portion of the area beneath the canopy in the sample. Small differences in soil water content between the dripline and $3 \mathrm{~m}$ beyond the dripline are reflected by small differences in herbage standing crop. Since small $(2 \mathrm{~m})$ and large $(6 \mathrm{~m})$ trees result in similar levels of herbage reduction beneath their canopies, herbage reduction on area basis is probably equivalent to the herbage

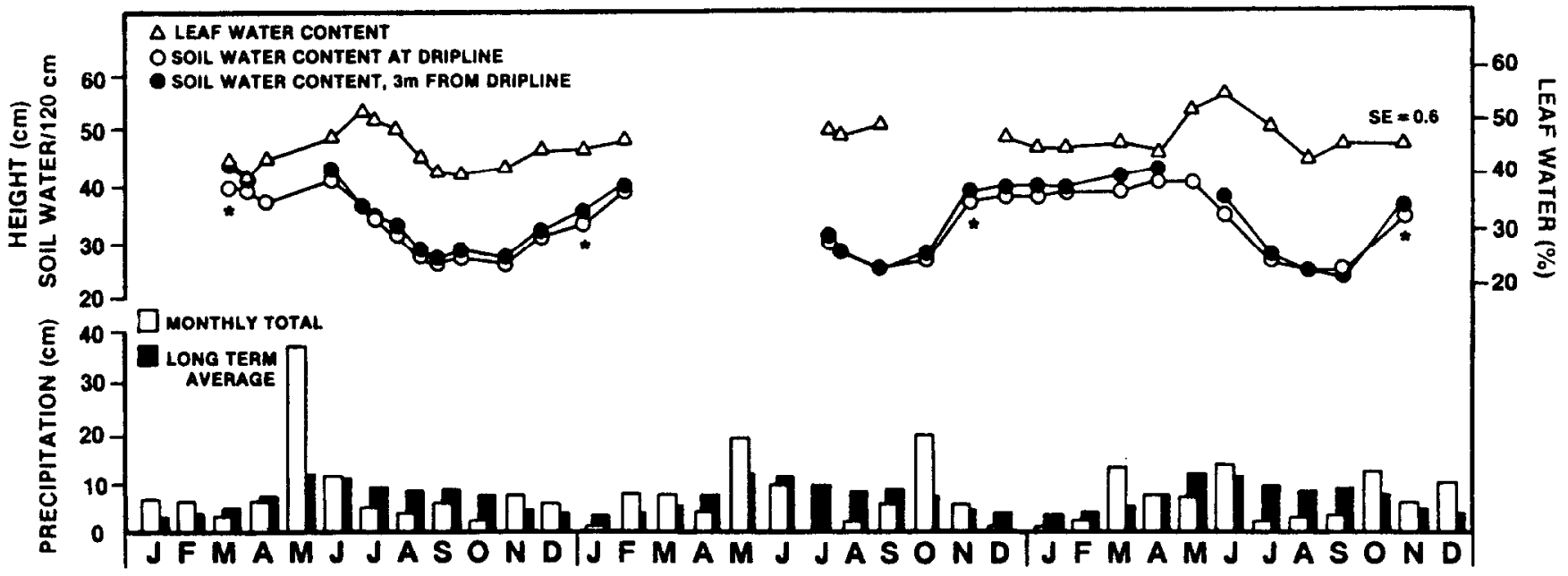

1982

1983

1984

Fig. 2. Leaf water content of eastern redcedar trees, total soil water content at 2 locations around eastern redcedar trees, and monthly precipitation at Stillwater, Oklahoma. Soil water content at the dripline and $3 \mathrm{~m}$ beyond the dripline are significantly different on those dates marked with an asterisk (*). 
reduction under the canopy of trees between 2 and $6 \mathrm{~m}$ in height. This is quite different from the substantial herbage reduction associated with root activity beyond the canopies of juniper in the more arid rangelands of the western U.S. (Springfield 1976).

While the herbage reduction beneath the eastern redcedar tree canopy is sizable, and the small amount of herbage present under the canopy may be unavailable to large herbivores, herbage reduction from open stands (less than 50 trees/ha) of eastern redcedar trees (up to $6 \mathrm{~m}$ tall) is probably of minimal magnitude and importance to livestock production in the tallgrass prairie. However, eastern redcedar canopies will eventually become sufficiently closed so as to limit forage available for cattle when stocking is based upon long-term stocking rates. Thus, the relationship between canopy cover and forage availability and eventually between canopy cover and livestock performance should be quantified so that economic evaluations can be made for eastern redcedar control. Economic benefits derived from controlling eastern redcedar are more a result of preventing further invasion and maintaining a low canopy cover of eastern redcedar than from initial increases in herbage production.

Range managers should also consider that, over time, increasing eastern redcedar canopy cover may reduce the effectivenss of prescribed burning, currently the least costly method of controlling eastern redcedar in tallgrass prairie (Rollins 1985). As trees become larger, more fine fuel is necessary for effective tree kill (Rollins 1985). Thus, on rangelands with high eastern redcedar density (more than 500 trees/ha), stocking rates may have to be reduced further to accumulate adequate fine fuel for control from prescribed burning. Eventually, canopy increases will reduce herbage production to the point of precluding a conventional prescribed burn.

Leaf water content was as low in late spring as in any other season of the year other than late summer. Thus, in terms of leaf ignition time and flammability, burning in late spring remains an appropriate prescription for eastern redcedar control.

\section{Literature Cited}

Arnold, J.F. 1964. Zonation of understory vegetation around a juniper tree. J. Range Manage. 17:41-42.

Amold, J.F., D.A. Jameson, and E.H. Reid. 1964. The pinyon-juniper type of Arizona: Effects of grazing, fire, and tree control. U.S. Dep. of Agr. Prod. Res. Rep. 84.

Arend, J.L. 1950. Influence of fire and soil on distribution of eastern redcedar in the Ozarks. J. For. 48:129-130.

Aro, R.S. 1971. Evaluation of pinyon-juniper conversion to grassland. J. Range Manage. 24:188-197.

Bunting, S.C., H.A. Wright, and W.H. Wallace. 1983. Seasonal variation in the ignition time of redberry juniper in west Texas. J. Range Manage. 36:169-171.

Clary, W.P. 1971. Effects of Utah juniper removal on herbage yields from Springerville soils. J. Range Manage. 24:373-378.

Clary, W.P. 1974. Response of herbaceous vegetation to felling of alligator juniper. J. Range Manage. 27:387-389.

Everett, R.L., and S.H. Sharrow. 1985. Response of grass species to tree harvesting in single leaf pinyon-Utah Juniper stands. USDA Forest Serv. Res. Paper. INT-334.

Hake, D.R., J. Powell, J.K. McPherson, P.L. Claypool, and G.L. Dunn. 1984. Water stress of tallgrass prairie plants in central Oklahoma. J. Range Manage. 37:147-151.

Jameson, D.A. 1967. The relationship of tree overstory and herbaceous understory vegetation. J. Range Manage. 20:247-249.

Jameson, D.A. 1970. Juniper root competition reduces basal area of blue grama. J. Range Manage. 23:217-218.

Launchbaugh, J.L., and C.E. Owensby. 1978. Kansas rangelands: their management based on a half century of research. Kansas Agr. Exp. Sta. Bull. 622. Manhattan.

Rollins, D. 1985. Controlling eastern redcedar with prescribed fire. p. 71-83. In: R.W. Wittwer and D.M. Engle (eds.). Proc. Eastern Redcedar in Oklahoma Conf. Coop. Ext. Serv. Oklahoma State Univ. E-849.

Springfield, H.W. 1976. Characteristics and management of southwestern pinyon-juniper ranges: The status of our knowledge. USDA Forest Serv. Res. Pap. RM-160.

Steuter, A.A., and H.A. Wright. 1983. Spring burning effects on redberry juniper-mixed grass habitats. J. Range Manage. 36:161-164.

Snook, E.C. 1985. Distribution of eastern redcedar on Oklahoma rangelands. p. 45-52. In: R.W. Wittwer and D.M. Engle (eds.) Proc. Eastern Redcedar in Oklahoma Conf. Coop. Ext. Serv. Oklahoma State Univ. E-849.

Van Haverbeke, D.F., and R.A. Read. 1976. Genetics of eastern redcedar. USDA Forest Serv. Res. Pap. WO-32. 